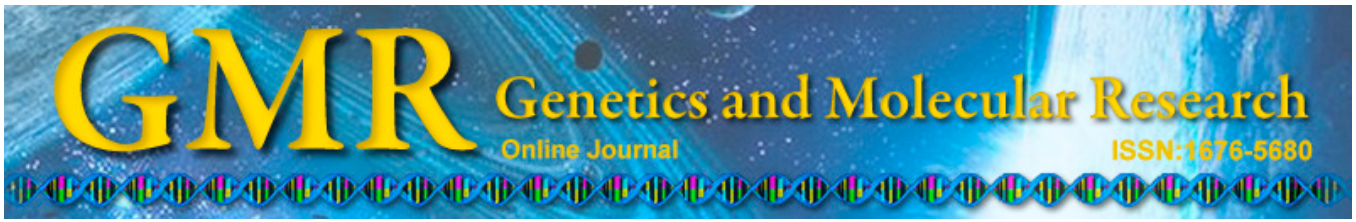

\title{
Association between the $F G B$ gene polymorphism and ischemic stroke: a meta-analysis
}

\author{
X.F. Zhang and T.Y. Luo \\ The First Affiliated Hospital of Chongqing Medical University, Chongqing, \\ China \\ Corresponding author: T.Y. Luo \\ E-mail: zhangxue_feng40@126.com \\ Genet. Mol. Res. 14 (1): 1741-1747 (2015) \\ Received March 5, 2014 \\ Accepted October 22, 2014 \\ Published March 6, 2015 \\ DOI http://dx.doi.org/10.4238/2015.March.6.21
}

ABSTRACT. To clarify the relationship between the $\beta$-fibrinogen $(F G B)$ genetic polymorphism $(-148 \mathrm{C}>\mathrm{T})$ and ischemic stroke, we identified studies by searching PubMed, EMBASE, and the Chinese National Knowledge Infrastructure (CKNI) databases. Data from eligible studies were extracted and subjected to meta-analysis. Publication bias was tested using a funnel plot. We identified 12 independent case-control studies containing 1536 ischemic stroke patients and 1329 control subjects. Our results showed that the $-148 \mathrm{C}>\mathrm{T}$ polymorphism in the $F G B$ gene was associated with an increased risk of ischemic stroke $[\mathrm{CC} v s(\mathrm{TT}+\mathrm{CT})$, odds ratio $=0.69$, $95 \%$ confidence interval $(\mathrm{CI})=0.59-0.80, \mathrm{P}<0.0001$; TT vs $(\mathrm{CC}+\mathrm{CT})$, odds ratio $=3.01,95 \% \mathrm{CI}=1.29-7.05 ; \mathrm{P}=0.01 ; \mathrm{T} v s \mathrm{C}$, odds ratio $=$ $1.32,95 \% \mathrm{CI}=1.15-1.52, \mathrm{P}<0.0001]$ by a meta-analysis. The results of our meta-analysis suggested that the $-148 \mathrm{C}>\mathrm{T}$ polymorphism in the $F G B$ gene is a susceptibility marker of ischemic stroke.

Key words: $\beta$-fibrinogen; Ischemic stroke; Meta-analysis 


\section{INTRODUCTION}

China is the world's most populous country, in which stroke is an enormous health care burden. Approximately 2 million people are affected by ischemic stroke each year in China (WHO, 2000). Previous studies suggested that the plasma fibrinogen level is associated with ischemic stroke risk (Wilhelmsen et al., 1984; Maresca et al., 1999). Fibrinogen is encoded by 3 separate genes located in a $50-\mathrm{kb}$ cluster on the long arm of chromosome 4 , which encodes for the $\alpha, \beta$, and $\gamma$ chains (Kant et al., 1985). The rate-limiting step in fibrinogen formation is the synthesis of the $\beta$-polypeptide chain regulated by a $\beta$-fibrinogen promoter (Roy et al., 1990). Polymorphisms in the $\beta$-fibrinogen gene $(F G B)$, including the $\beta-148 \mathrm{C}>\mathrm{T}$ polymorphism, have been shown to be related to elevated plasma fibrinogen levels (Guo et al., 2009; Yuan et al., 2010). Previous studies suggested that the $F G B-148 \mathrm{C}>\mathrm{T}$ polymorphism is associated with an increased risk of ischemic stroke in the Chinese population (Fu et al., 2005, 2006; Chen et al., 2007). However, each study included a relatively small sample size, which may lack sufficient power for detecting the slight effects of the $-148 \mathrm{C}>\mathrm{T}$ polymorphism on stroke. Meta-analysis may provide more credible evidence by systematically summarizing existing data. In the present study, we collected all published case-control studies to determine the relationship between the $-148 \mathrm{C}>\mathrm{T}$ polymorphism and stroke to perform a meta-analysis and to clarify the relationship between the $F G B$ gene $-148 \mathrm{C}>\mathrm{T}$ polymorphism and ischemic stroke.

\section{MATERIAL AND METHODS}

\section{Literature search and selection}

A publication search was carried out in PubMed, EMBASE, and the Chinese National Knowledge Infrastructure (CNKI) using the following search terms: ("fibrinogen" or " $\beta$-fibrinogen" or " $F G B$ ") and ("cerebral infarction" or "stroke" or "brain infarction" or "cerebrovascular disease") and ("SNP" or "polymorphism" or "mutation" or "genetics"). Publication language was restricted to English and Chinese, and the subjects were limited to Chinese in our search. Using an online retrieval and literature review, references obtained from the databases were reviewed again to ensure that no relevant studies were missed.

\section{Selection criteria}

Inclusion criteria were as follows: a) independently published case-control or cohort studies examining the relationship between $F G B$ polymorphism and stroke; b) with comprehensive direct or indirect statistical indicators: odds ratio (OR) or relative risk values and $95 \%$ confidence interval $(95 \% \mathrm{CI})$; and c) similar themes and methods, such as case-control or cohort studies examining the relationship between the $F G B$ gene polymorphism and stroke. The studies were excluded if relevant data were not available or if there was heterogeneity in the gene polymorphisms in the control population. For the heterogeneity test method, the Q-test and the $\mathrm{I}^{2}$ test included in the RevMan 5.2 software were used.

\section{Data extraction}

The research design, enrolled patients, observation results of the literature, and se- 
lected trials were evaluated by the author. The Cochrane Handbook 5.2 quality evaluation criteria was used to assess the methodological quality of the studies such as study included subjects and impact factors, the source of the cases and controls, matching, age, and gender. To determine data quality by the quality of the determined literature, duplicate studies, those with poor quality or little information, and those including special selection for laboratory samples were excluded; relevant data were extracted from the studies included.

\section{Statistical analysis}

For each study, we first examined whether the genotype distribution in controls was consistent with Hardy-Weinberg equilibrium using the $\chi^{2}$ test. Meta-analysis was performed using the RevMan 5.2 software provided by the Cochrane Collaboration. The Q-test and the $\mathrm{I}^{2}$ test were used to examine the heterogeneity between each study. Using the heterogeneity test, if $\mathrm{P}>0.05$, the fixed-effect model was selected, and if $\mathrm{P}<0.05$, the random-effect model was selected to merge the OR values. $\mathrm{P}<0.05$ was considered to be significant. Analysis of sensitivity included the difference of point estimations and confidence intervals of the combined effect values of different models to observe whether it changed the result; poor-quality studies were excluded or reanalyzed according to the quality evaluation criteria to determine whether it changed the findings. To test for publication bias, the RevMan 5.2 statistical software was used to construct a funnel plot.

\section{RESULTS}

\section{Literature search}

A total of 313 studies were preliminarily detected, and 301 studies were excluded because of duplicate publication and nonclinical-based research literature. Twelve studies (LV et al., 2003; Liu et al., 2004; Qian et al., 2004; Pan et al., 2005; Song et al., 2005; Xu et al., 2005; Ma et al., 2006; Fu et al., 2006; Song et al., 2006; Lu et al., 2007; Liu and Zhao, 2008; Yuan et al., 2010) met the inclusion criteria and were included in the present study.

\section{Study characteristics}

The characteristics of the studies included are summarized in Table 1 . The 12 studies included a total of 1536 ischemic stroke cases and 1329 control subjects. All subjects included in these studies were of Chinese descent. A classic polymerase chain reaction assay was performed in all studies. The genotyping method in all studies was polymerase chain reaction-restriction fragment length polymorphism, and the genotype distributions among the controls of all studies were in agreement with Hardy-Weinberg equilibrium.

\section{Meta-analysis}

The association between the $-148 \mathrm{C}>\mathrm{T}$ polymorphism and susceptibility to stroke was analyzed in 12 independent studies with 1536 stroke patients and 1329 control subjects. The results of the meta-analysis are shown in Figures 1,2, and 3. These 3 figures indicate the correlation between ischemic stroke and the $F G B-148 \mathrm{C}>$ T polymorphism in the 12 case-control studies. 
Table 1. Characteristics of the studies included.

\begin{tabular}{|c|c|c|c|c|c|c|c|c|}
\hline \multirow[t]{2}{*}{ Author } & \multirow[t]{2}{*}{ Year } & \multirow[t]{2}{*}{ Country } & \multirow[t]{2}{*}{ Genotyping methods } & \multirow[t]{2}{*}{ Groups } & \multirow[t]{2}{*}{ No. } & \multicolumn{3}{|c|}{$-148 \mathrm{C}>\mathrm{T}(\mathrm{N})$} \\
\hline & & & & & & $\mathrm{CC}$ & $\mathrm{CT}$ & TT \\
\hline \multirow[t]{2}{*}{$\mathrm{Fu} \mathrm{Y}$} & \multirow[t]{2}{*}{2006} & \multirow[t]{2}{*}{ China } & \multirow[t]{2}{*}{ PCR-RFLP } & Case & 132 & 75 & 50 & 7 \\
\hline & & & & Control & 171 & 102 & 58 & 11 \\
\hline \multirow[t]{2}{*}{ Liu CF } & \multirow[t]{2}{*}{2004} & \multirow[t]{2}{*}{ China } & \multirow[t]{2}{*}{ PCR-RFLP } & Case & 90 & 43 & 39 & 8 \\
\hline & & & & Control & 102 & 64 & 34 & 4 \\
\hline \multirow[t]{2}{*}{ Liu Z } & \multirow[t]{2}{*}{2008} & \multirow[t]{2}{*}{ China } & \multirow[t]{2}{*}{ PCR-RFLP } & Case & 220 & 105 & 85 & 30 \\
\hline & & & & Control & 140 & 84 & 49 & 7 \\
\hline \multirow[t]{2}{*}{ Lu SJ } & \multirow[t]{2}{*}{2007} & \multirow[t]{2}{*}{ China } & \multirow[t]{2}{*}{ PCR-RFLP } & Case & 148 & 72 & 63 & 13 \\
\hline & & & & Control & 130 & 79 & 45 & 6 \\
\hline \multirow[t]{2}{*}{ Lv B } & \multirow[t]{2}{*}{2003} & \multirow[t]{2}{*}{ China } & \multirow[t]{2}{*}{ PCR-RFLP } & Case & 151 & 70 & 65 & 16 \\
\hline & & & & Control & 113 & 62 & 47 & 4 \\
\hline \multirow[t]{2}{*}{$\mathrm{Ma} \mathrm{AJ}$} & \multirow[t]{2}{*}{2006} & \multirow[t]{2}{*}{ China } & \multirow[t]{2}{*}{ PCR-RFLP } & Case & 151 & 85 & 63 & 3 \\
\hline & & & & Control & 101 & 70 & 30 & 1 \\
\hline \multirow[t]{2}{*}{ Pan XD } & 2005 & China & PCR-RFLP & Case & 69 & 41 & 26 & 2 \\
\hline & & & & Control & 60 & 41 & 18 & 1 \\
\hline Qian JJ & 2004 & China & PCR-RFLP & Case & 102 & 66 & 30 & 6 \\
\hline & & & & Control & 90 & 43 & 39 & 8 \\
\hline Song YQ & 2005 & China & PCR-RFLP & Case & 88 & 38 & 42 & 8 \\
\hline & & & & Control & 80 & 47 & 27 & 6 \\
\hline Song YQ & 2006 & China & PCR-RFLP & Case & 135 & 53 & 56 & 26 \\
\hline & & & & Control & 120 & 65 & 43 & 11 \\
\hline $\mathrm{XuF}$ & 2005 & China & PCR-RFLP & Case & 90 & 52 & 32 & 6 \\
\hline & & & & Control & 60 & 47 & 17 & 2 \\
\hline Yuan XD & 2010 & China & PCR-RFLP & Case & 160 & 101 & 47 & 12 \\
\hline & & & & Control & 162 & 112 & 42 & 8 \\
\hline
\end{tabular}

The heterogeneity test of the various studies revealed heterogeneous results $\left(\mathrm{P}=0.04, \mathrm{I}^{2}\right.$ $\left.=45 \% ; \mathrm{P}<0.01, \mathrm{I}^{2}=86 \% ; \mathrm{P}=0.14, \mathrm{I}^{2}=31 \%\right)$; therefore, the fixed-effect or the random-effect models were used for analysis. Overall, the association between the $F G B-148 \mathrm{TT} / \mathrm{CT}$ genotype and higher risk of ischemic stroke was observed in the recessive model $(\mathrm{OR}=0.69,95 \% \mathrm{CI}=$ 0.59-0.80; $\mathrm{P}<0.0001$; Figure 1$)$ and in the dominant model $(\mathrm{OR}=3.01,95 \% \mathrm{CI}=1.29-7.05$; $\mathrm{P}=0.01$; Figure 2). Additionally, the $-148 \mathrm{~T}$ allele carriers were found to be associated with an increased risk of ischemic stroke $(\mathrm{OR}=1.32,95 \% \mathrm{CI}=1.15-1.52 ; \mathrm{P}<0.0001$; Figure 3$)$.

\begin{tabular}{|c|c|c|c|c|c|c|c|c|}
\hline Study or Subqroup & $\begin{array}{l}\text { Case } \\
\text { Events }\end{array}$ & Total & $\begin{array}{c}\text { Contr } \\
\text { Events }\end{array}$ & $\begin{array}{l}\text { ol } \\
\text { Total }\end{array}$ & \multicolumn{2}{|c|}{\begin{tabular}{cc}
\multicolumn{1}{c}{ Odds Ratio } \\
Weight & M-H, Fixed, 95\% Cl
\end{tabular}} & \multicolumn{2}{|c|}{$\begin{array}{c}\text { Odds Ratio } \\
\text { M-H, Fixed, 95\% Cl }\end{array}$} \\
\hline FuY 2006 & 75 & 132 & 102 & 171 & $9.4 \%$ & $0.89[0.56,1.41]$ & $\longrightarrow$ & \\
\hline Liu CF 2004 & 43 & 90 & 64 & 102 & $7.6 \%$ & $0.54[0.31,0.97]$ & & \\
\hline Liu Z 2008 & 105 & 220 & 84 & 140 & $13.1 \%$ & $0.61[0.40,0.94]$ & & \\
\hline Lu SJ 2007 & 72 & 148 & 79 & 130 & $10.5 \%$ & $0.61[0.38,0.99]$ & & \\
\hline LVB 2003 & 70 & 151 & 62 & 113 & $9.3 \%$ & $0.71[0.44,1.16]$ & & \\
\hline Ma A J 2006 & 85 & 151 & 70 & 101 & $8.9 \%$ & $0.57[0.34,0.97]$ & & \\
\hline Pan XD 2005 & 41 & 69 & 41 & 60 & $4.3 \%$ & $0.68[0.33,1.40]$ & & \\
\hline Qian J.J 2004 & 66 & 102 & 43 & 90 & $3.9 \%$ & $2.00[1.12,3.58]$ & & \\
\hline Song $\mathrm{YQ} 2005$ & 38 & 88 & 47 & 80 & $6.8 \%$ & $0.53[0.29,0.99]$ & & \\
\hline Song $Y Q 2006$ & 53 & 135 & 65 & 120 & $10.2 \%$ & $0.55[0.33,0.90]$ & & \\
\hline XuF 2005 & 52 & 90 & 47 & 60 & $5.8 \%$ & $0.38[0.18,0.80]$ & & \\
\hline Yuan XD 2010 & 101 & 160 & 112 & 162 & $10.0 \%$ & $0.76[0.48,1.21]$ & & \\
\hline Total $(95 \% \mathrm{Cl})$ & & 1536 & & 1329 & $100.0 \%$ & $0.69[0.59,0.80]$ & & \\
\hline Total events & 801 & & 816 & & & & & \\
\hline \multicolumn{7}{|c|}{$\begin{array}{l}\text { Heterogeneity: } \mathrm{Chi}^{2}=20.11, \mathrm{df}=11(\mathrm{P}=0.04) ; F^{2}=45 \% \\
\text { Test for owerall effect: } Z=4.92(\mathrm{P}=0.00001)\end{array}$} & $\begin{array}{ll}0.2 & 0.5 \\
\text { Favors [case] }\end{array}$ & Favors [ \\
\hline
\end{tabular}

Figure 1. Forest plot of stroke and the $-148 \mathrm{C}>\mathrm{T}$ polymorphism $(\mathrm{CC}$ vs $\mathrm{TT}+\mathrm{CT})$. The horizontal lines correspond to the study-specific OR and $95 \% \mathrm{CI}$. The area of the squares reflects the study-specific weight. The diamond represents the pooled results of OR and $95 \% \mathrm{CI}$. 


\begin{tabular}{|c|c|c|c|c|c|c|c|c|}
\hline Study or Subqroup & \multicolumn{2}{|c|}{ Case } & \multicolumn{2}{|c|}{ Control } & Weight & $\begin{array}{c}\text { Odds Ratio } \\
\text { M-H, Random, } 95 \% \mathrm{Cl}\end{array}$ & \multicolumn{2}{|c|}{$\begin{array}{c}\text { Odds Ratio } \\
\text { M-H, Random, } 95 \% \mathrm{Cl}\end{array}$} \\
\hline Fu $Y 2006$ & 30 & 132 & 11 & 171 & $9.6 \%$ & $4.28[2.05,8.91]$ & & $\rightarrow-$ \\
\hline Liu CF 2004 & 13 & 90 & 4 & 102 & $8.7 \%$ & $4.14[1.30,13.19]$ & & \\
\hline Liu Z 2008 & 16 & 220 & 7 & 140 & $9.2 \%$ & $1.49[0.60,3.72]$ & & \\
\hline Lu S.J 2007 & 3 & 148 & 6 & 130 & $8.0 \%$ & $0.43[0.10,1.75]$ & & - \\
\hline L'V B 2003 & 2 & 151 & 4 & 113 & $7.3 \%$ & $0.37[0.07,2.03]$ & & \\
\hline Ma As 2006 & 6 & 151 & 1 & 101 & $6.3 \%$ & $4.14[0.49,34.90]$ & & \\
\hline Pan XD 2005 & 8 & 69 & 1 & 60 & $6.3 \%$ & $7.74[0.94,63.79]$ & & \\
\hline Qian JJ 2004 & 26 & 102 & 8 & 90 & $9.3 \%$ & $3.51[1.50,8.22]$ & & \\
\hline Sang $Y Q 2005$ & 6 & 88 & 6 & 80 & $8.6 \%$ & $0.90[0.28,2.92]$ & & \\
\hline Bang YQ 2006 & 12 & 135 & 11 & 120 & $9.3 \%$ & $0.97[0.41,2.28]$ & & \\
\hline $\mathrm{XuF} 2005$ & 52 & 90 & 2 & 60 & $7.9 \%$ & $39.68[9.12,172.66]$ & & \\
\hline Yuan XD 2010 & 101 & 160 & 8 & 162 & $9.5 \%$ & $32.95[15.11,71.88]$ & & \\
\hline Total $(95 \% \mathrm{Cl})$ & & 1536 & & 1329 & $100.0 \%$ & $3.01[1.29,7.05]$ & & \\
\hline Total events & 275 & & 69 & & & & & \\
\hline $\begin{array}{l}\text { Heterogeneity: Tau } \\
\text { Test for overall effect }\end{array}$ & $\begin{array}{l}1.83 ; \mathrm{chi}^{2} \\
z=2.540\end{array}$ & $\begin{array}{l}=77.1 \\
P=0.0\end{array}$ & $8, d f=1$ & $1(P=0$ & $0.00001) ;$ & $I^{2}=86 \%$ & $\begin{array}{cc}0.002 & 0.1 \\
\text { Favors [case] }\end{array}$ & Favors [co \\
\hline
\end{tabular}

Figure 2. Forest plot of stroke and the $-148 \mathrm{C}>\mathrm{T}$ polymorphism ( $\mathrm{TT} v s \mathrm{CC}+\mathrm{CT}$ ). The horizontal lines correspond to the study-specific OR and $95 \%$ CI. The area of the squares reflects the study-specific weight. The diamond represents the pooled results of $\mathrm{OR}$ and $95 \% \mathrm{CI}$.

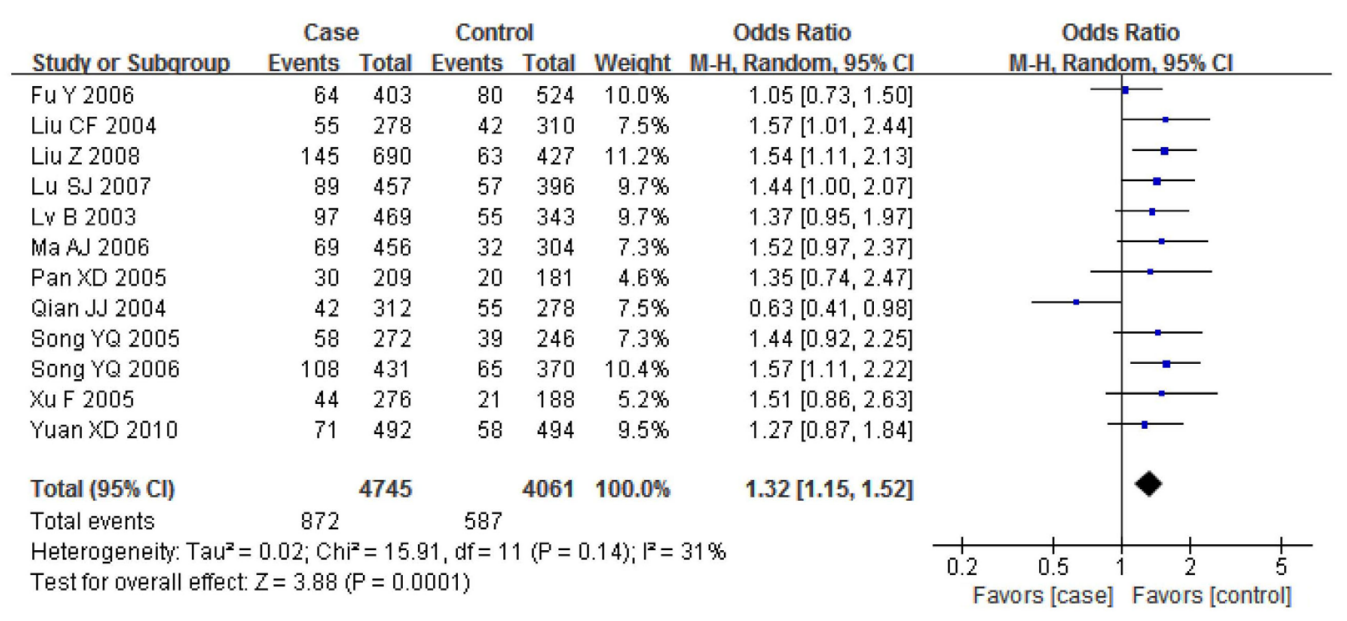

Figure 3. Forest plot of stroke and the $-148 \mathrm{C}>\mathrm{T}$ polymorphism $(\mathrm{T} v s \mathrm{C})$. The horizontal lines correspond to the study-specific OR and $95 \%$ CI. The area of the squares reflects the study-specific weight. The diamond represents the pooled results of OR and $95 \% \mathrm{CI}$. In this analysis, the fixed-effect model was used.

\section{Publication bias}

The RevMan 5.2 software was used to analyze publication bias; the funnel plot (Figure 4) showed that the points were evenly distributed and symmetrical, and most points were within the $95 \%$ CI. The shape of the funnel plots showed no clear asymmetry compared to the Egger test and no statistical evidence of bias. These results indicate that there was no publication bias and that the results of the study were credible. 


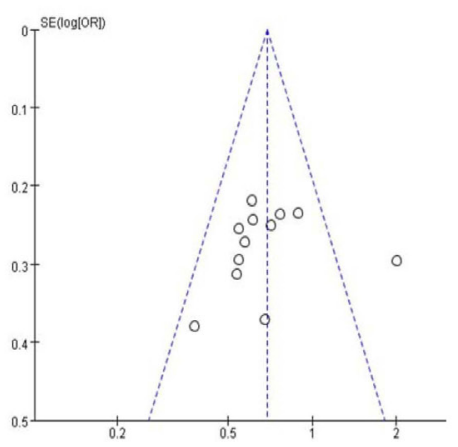

A

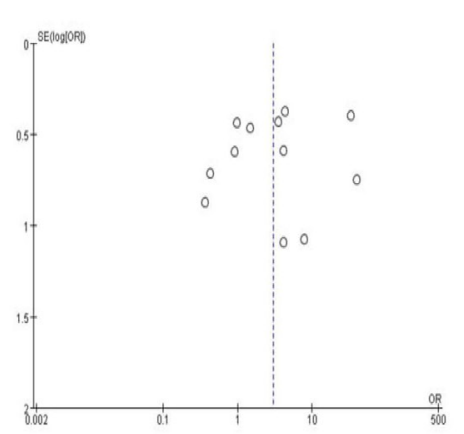

B

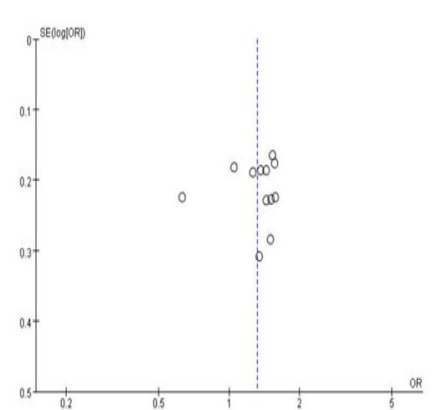

C

Figure 4. Begg's funnel plot for publication bias tests. Each point represents a separate study for the indicated association. Log OR represents natural logarithm of OR. Vertical line represents the mean effect size. A. CC vs $(\mathrm{TT}+\mathrm{CT}) ;$ B. TT vs $(\mathrm{CC}+\mathrm{CT}) ; \mathbf{C} . \mathrm{T}$ vs $\mathrm{C}$.

\section{DISCUSSION}

In the present study, we found that the $-148 \mathrm{C}>\mathrm{T}$ polymorphism in the $F G B$ gene was significantly associated with ischemic stroke in a Chinese population using a meta-analysis. Meta-analysis combines comparable studies to increase the sample size and statistical power, drawing a more compelling result. In the present study, no publication bias was observed, all subjects were Chinese, and the genotypes in all studies were detected using genetic DNA from blood samples with the polymerase chain reaction-restriction fragment length polymorphism genotyping method. Genotypes in all studies were evaluated for quality control. Genotype distribution of controls in all studies was consistent with Hardy-Weinberg equilibrium. Polymorphisms in $F G B$, particularly those involved in the rate-limiting steps of $\beta$-chain formation, have been shown to be closely related to elevated plasma fibrinogen level and ischemic stroke (Zhang et al., 2003; Zhao et al., 2003). In the present study, the results of 12 studies were combined to analyze the relationship between the $-148 \mathrm{C}>\mathrm{T}$ polymorphism and ischemic stroke. The results showed that there was a $32 \%$ increased risk of stroke in patients with the T allele compared with the wild-type $\mathrm{C}$ allele. Thus, the $\mathrm{T}$ allele may be a genetic risk factor that increases the susceptibility to stroke at protein and genetic levels.

However, there were some limitations to this meta-analysis. Although the genotyping methods used in all studies were the same, other clinical factors such as age, gender, and different therapies in each study may lead to bias. Determining whether these factors influence the results requires further investigation.

In conclusion, our study suggested that the $-148 \mathrm{C}>\mathrm{T}$ polymorphism in the $F G B$ gene was associated with a significantly increased risk of ischemic stroke in the Chinese population.

\section{REFERENCES}

Chen XC, Xu MT, Zhou W, Han CL, et al. (2007). A meta-analysis of relationship between beta-fibrinogen gene -148C/T polymorphism and susceptibility to cerebral infarction in Han Chinese. Chin. Med. J. 120: 1198-1202.

Fu Y, Wei X, Ni PH, Ying YY, et al. (2005). The relationship between the five beta-fibrinogen gene polymorphisms and 
cerebral infarction. Zhonghua Nei Ke Za Zhi 44: 914-917.

Fu Y, Ni PH, Liu JR, Ying YY, et al. (2006). Study on haplotypes of five $\beta$-fibrinogen genes in Han population. $J$. Shanghai Jiaotong Univ. (Med. Sci.) 26: 758-760.

Guo X, Zhang D and Zhang X (2009). Fibrinogen gene polymorphism (beta-148C/T) in Uygur patients with cerebral infarction. Neurol. Res. 31: 381-384.

Kant JA, Fornace AJ Jr, Saxe D, Simon MI, et al. (1985). Evolution and organization of the fibrinogen locus on chromosome 4: gene duplication accompanied by transposition and inversion. Proc. Natl. Acad. Sci. U. S. A. 82: 2344-2348.

Liu CF, Qian JJ and Zhao KR (2004). Study on the $\beta$-fibrinogen gene $-455 \mathrm{~A} / \mathrm{G}$ and $-148 \mathrm{C} / \mathrm{T}$ polymorphism and cerebral infarction. Chin. J. Neurol. 37: 90-91.

Liu $\mathrm{Z}$ and Zhao B (2008). The association of beta fibrinogen -148C $>\mathrm{T}$ gene and plasminogen activator $1-6754 \mathrm{G} / 5 \mathrm{G}$ gene polymorphism with cerebral infarction. Nerv. Dis. Ment. Health 8: $94-97$ (in Chinese).

Lu SJ, Zhao B and Chen YS (2007). Study on the relation between beta fibrinogen $-148 \mathrm{C}>\mathrm{T}$ gene polymorphism and cerebral infarction. Chin. J. Nerv. Ment. Dis. 33: 425-428.

Lv B, Zhao B, Xing YQ, Xu ZE, et al. (2003). The study on the polymorphism of beta fibrinogen gene $-148 \mathrm{C}>\mathrm{T}$ in the patients with cerebral infarction. J. Clin. Neurol. 16: 202-205.

Ma AJ, Pan XD, Zhang CS, Xing Y, et al. (2006). A linkage between beta-fibrinogen gene -148C/T polymorphism and cerebral infarction. Zhonghua Yi Xue Yi Chuan Xue Za Zhi 23: 202-204.

Maresca G, Di Blasio A, Marchioli R and Di Minno G (1999). Measuring plasma fibrinogen to predict stroke and myocardial infarction: an update. Arterioscler. Thromb. Vasc. Biol. 19: 1368-1377.

Pan XD, Ma AJ, Zou ZQ, Zhang CS, et al. (2005). Study of beta fibrinogen gene -148C $>$ T polymorphism and plasma fibrinogen levels in young patients with acute cerebral infarction. J. Clin. Neurol. 18: 40-44.

Qian JJ, Liu CF and Yue KR (2004). The relationship between $\beta$-fibrinogen gene $-455 \mathrm{~A} / \mathrm{G}$ and $-148 \mathrm{C} / \mathrm{T}$ polymorphism and cerebral infarction with carotid atherosclerosis. Jiangsu Med. J. 30: 377-379.

Roy SN, Mukhopadhyay G and Redman CM (1990). Regulation of fibrinogen assembly. Transfection of Hep G2 cells with B beta cDNA specifically enhances synthesis of the three component chains of fibrinogen. J. Biol. Chem. 265: 6389-6393.

Song YQ, Zou HL, Song XJ and Wang W (2005). Fibrinogen gene polymorphism (beta-148C >T) in patients with cerebral infarction. Cerebrovasc. Dis. Foreign Med. Sci. 13: 895-897.

Song YQ, Zou HL and Zhang C (2006). Correlation between the polymorphism of platelet glycoprotein GPIb $\alpha$ Kozak gene and transient ischemic attack. Chin. J. Med. Genet. 23: 561-564.

World Health Organization (WHO) (2000). The World Health Report 2000. Health Systems: Improving Performance. World Health Organization, Geneva.

Wilhelmsen L, Svärdsudd K, Korsan-Bengtsen K, Larsson B, et al. (1984). Fibrinogen as a risk factor for stroke and myocardial infarction. N. Engl. J. Med. 311: 501-505.

Xu F, Ni PH, Ying YY and Hu YQ (2005). Fibrinogen B $\beta$ gene -148 C>T polymorphism in stroke. J. Diagn. Concepts Pract. 4: 38-41.

Yuan XD, Wang SJ, Xu YR, Li J, et al. (2010). The relationship of muti-locus gene polymorphisms, functional expression of fibrinogen B $\beta$-chain and the type of cerebral infarction. Zhong Guo Mian Yi Xue Za Zhi 26: 356-358.

Zhang XH, Xu G, Zhao XY, Hou T, et al. (2003). Study of fibrinogen B $\beta$ gene $-148 \mathrm{C}>\mathrm{T}$ gene polymorphism in patients with coronary heart disease and stroke. Chin. J. Emerg. Med. 12: 683-685.

Zhao B, LV B, Xing YQ, Xu ZE, et al. (2003). The beta fibrinogen gene -148C $>$ T polymorphism and its association with plasma fibrinogen's function and level in cerebral infarction. Chin. J. Neurol. 36: 450-454. 